\title{
Root Analogous Solid Waste Management System (RA-MSW for Biocells)
}

\author{
Ahmad Qasaimeh \\ Department of Civil Engineering, Faculty of Engineering, Jerash University, Jerash, Jordan. \\ Email: argg22@yahoo.com
}

Received May $6^{\text {th }}, 2012$; revised June $8^{\text {th }}, 2012$; accepted July $10^{\text {th }}, 2012$

\begin{abstract}
Root Analogous Municipal Solid Waste System "RA-MSW" is a novel management system that manages waste, biogas, and leachate in bioreactor landfill. Different than conventional disposal at landfills, waste is penetrated by synthetic roots that serve dual mission for biogas collection and leachate recirculation. RA-MSW roots are permeable hydrophobic polymer material that are formed on-place or prefabricated at factory from recyclable material available on the dumping area. Since the material is hydrophobic, it does not contain water in the voids providing more space for gas transport and collection. The roots are also interchangeably used for leachate recirculation where the parameters of water content, nutrients, $\mathrm{pH}$, and temperature are optimized to enhance biogas production simultaneously with leachate treatment. RA-MSW provides new approach of waste management and control; it has new virtues of landfill operation; new material medium for biogas collection; new biocell design configuration; new manipulation for leachate and biogas. The approach adds new merits for solid waste management, bio-energy utilization, and the concept of $5 \mathrm{R}$ 's cycle for MSW management.
\end{abstract}

Keywords: Root Analogy RA; Municipal Solid Waste Management; Biogas; Leachate; Biocell; 5 R's Cycle

\section{Introduction}

Leachate and biogas are two discharges that are characteristic of municipal solid waste (MSW) landfills. The anaerobic decomposition of landfilled MSW generates large amounts of gas composed of $50 \%-60 \% \mathrm{CH}_{4}$ (by volume), $40 \%-50 \% \mathrm{CO}_{2}$, and other trace gases such as nitrogen and volatile organic hydrocarbons [1,2]. Methane $\left(\mathrm{CH}_{4}\right)$ gas is one of the most important GHGs because its global warming potential is more than 20 times of carbon dioxide $\left(\mathrm{CO}_{2}\right)$ [3]. Atmospheric $\mathrm{CH}_{4}$ gas has more than doubled in concentration over the last 150 years [4].

Leachate recirculation is one option for inexpensive leachate disposal and for reducing the cost of post-closure care and long-term liability $[5,6]$. It could participate to improve leachate quality; reduce volume of leachate to be treated; and enhance gas production [7]. Leachate recirculation reduces waste stabilization time. In addition, it is effective in enhancing gas production and improving leachate quality especially in terms of COD. Leachate recirculation has a positive effect on $\mathrm{CH}_{4}$ formation [8].

Landfill gas production rate is influenced by functional parameters such as abiotic factors and landfill operation procedures [9]. The abiotic factors of concern can be summarized as: $\mathrm{pH}$, nutrients, inhibitors, temperature, and water content, while the landfill operation procedures of concern can be summarized as: waste composition, sewage sludge addition, shredding, compaction, soil cover, recirculation of leachate, and pre-composting.

The methane producing bacteria is called methanogens which operate within $6-8 \mathrm{pH}$ in methanogenesis process. Anaerobic ecosystem requires much less nitrogen $\left(\mathrm{N}_{2}\right)$ and phosphorous $(\mathrm{P})$ than the aerobic system does. The optimal ratio for organic matter (as COD), $\mathrm{N}_{2}$ and $\mathrm{P}$ content, is 100:0.44:0.08 [9]. Nutrients and metal supplementation have a positive effect on biogas production rate [10].

The temperature for mesophilic bacteria is in the range of $30^{\circ} \mathrm{C}-35^{\circ} \mathrm{C}$, while $45^{\circ} \mathrm{C}-65^{\circ} \mathrm{C}$ is for the thermophilic bacteria. The active temperature for methanogens is in the range of $30^{\circ} \mathrm{C}-50^{\circ} \mathrm{C}$. The optimum temperature range of gas generation is between $30^{\circ} \mathrm{C}-45^{\circ} \mathrm{C}$ during the main landfill gas generation phase [11]. The change of temperature will have an impact on the growth and the activity of the microorganisms [12].

The range of moisture content in a typical landfill is 15 to $40 \%$ with a typical average of $30 \%$ [11]. Some studies have indicated that refuse samples containing greater than $55 \%(\mathrm{wt} / \mathrm{wt})$ moisture content produced increased 
amounts of $\mathrm{CH}_{4}$ while those that contained less than $33 \%$ moisture content did not produce any $\mathrm{CH}_{4}[13]$. The rate of gas generation increases with the increment of moisture in landfill site [14]. The water content in landfill sites assists to exchange of substrate, nutrients, buffer, dilution of inhibitors, and spreading of microorganisms [15].

The MSW at landfill undergo biochemical processes that are consisted of three phases: hydrolysis, acidification, and methanogenesis. The first and most important part in the biodegradation process of organic material in sanitary landfill is the hydrolysis, which is likely to be the rate-limiting step for methane production from solid waste [16]. First-order kinetics is used to represent the hydrolysis of refuse constituents:

$$
\frac{\mathrm{d} C_{s i}}{\mathrm{~d} t}=-K_{h i} C_{s i} \text { as } C_{(S) i}+\mathrm{H}_{2} \mathrm{O} \rightarrow C_{(a q)}
$$

where: $K_{h i}$ is first-order hydrolysis rate constant of refuse constituent $i\left(\right.$ day $\left.^{-1}\right), C_{(S) i}$ is solid organic carbon concentration of refuse constituent $i\left(\mathrm{~kg} / \mathrm{m}^{3}\right)$, and $C_{(a q) i}$ is aqueous organic carbon concentration of refuse constituent $i$ $\left(\mathrm{kg} / \mathrm{m}^{3}\right)$.

The second phase of the biochemical process is the acidification, where carbon dioxide and acetate are produced from the biodegradation of organic matter. In this phase, the $\mathrm{pH}$ value has important effect on the methanogens [17]. The third phase is the methanogenesis, where the acetic acid is converted to methane and carbon dioxide.

The mass balance coupled with the Monod formula is used to describe the microbial growth within landfill:

Mass balance:

$$
C_{(X)}=C_{(X)}^{g}-C_{(X)}^{d}
$$

Monod formula:

$$
\frac{\mathrm{d} X}{\mathrm{~d} t}=\frac{\mu_{\max } S}{K_{s}+S} X
$$

where: $C_{\left(\frac{X}{3}\right)}$ is net formation rate of carbon concentration $\left(\mathrm{kg} / \mathrm{m}^{3} \cdot\right.$ day $), C_{(X)}^{g}$ is generation rate of carbon concentration $\left(\mathrm{kg} / \mathrm{m}^{3} \cdot\right.$ day $), C_{(X)}^{d}$ is depletion rate of carbon concentration $\left(\mathrm{kg} / \mathrm{m}^{3} \cdot \mathrm{day}\right),(\mathrm{d} X / \mathrm{d} t)$ is rate of microbial growth $\left(\mathrm{kg} / \mathrm{m}^{3} \cdot\right.$ day), $\mu_{\max }$ is maximum rate of substrate utilization $\left(\right.$ day $\left.^{-1}\right), X$ is microbial concentration $\left(\mathrm{kg} / \mathrm{m}^{3}\right)$, $S$ is substrate concentration $\left(\mathrm{kg} / \mathrm{m}^{3}\right)$, and $K_{S}$ is half saturation constant $\left(\mathrm{kg} / \mathrm{m}^{3}\right)$ [17].

The most commonly used reaction rate equation in engineering practice for gas production estimation is:

$$
\frac{\mathrm{d} S}{\mathrm{~d} t}=-\frac{k_{m}}{K_{s}} X S ; S \ll K_{s}
$$

where: $\mathrm{d} S / \mathrm{d} t$ : rate of substrate utilization $\left(\mathrm{kg} / \mathrm{m}^{3} \cdot \mathrm{day}\right)$, $k_{m}$ : maximum utilization coefficient $\left(\right.$ day $\left.^{-1}\right), X$ : is micro- bial concentration $\left(\mathrm{kg} / \mathrm{m}^{3}\right), S$ : substrate concentration $\left(\mathrm{kg} / \mathrm{m}^{3}\right), K_{S}$ : half saturation constant $\left(\mathrm{kg} / \mathrm{m}^{3}\right)$.

The above equation implies an environment capable of supporting biological activity in accordance with substrate availability [18]. A necessary condition in applying this kinetic model to the decomposition of organic matter in a sanitary landfill is that the organic matter is limiting for the rate determining by methanogenic bacteria [19]. Although the rate determining nature of methanogenic bacteria has been studied in great detail for applications to anaerobic digestion, it is difficult to directly apply this information to organic decomposition in sanitary landfills because of the undefined nature of the landfill environment [19].

The gas pressure and composition vary during the life of the landfill. The methane and carbon dioxide generation increases the pressure gradients leading to the gas advective flow. The concentration gradients lead to the gas diffusion. Following the path of least resistance, gas will migrate either vertically to the atmosphere or laterally beyond landfill boundaries in surrounding geological formations. In the latter case, gas eventually reaches the atmosphere [20].

In isobaric systems, gas transport occurs by diffusion, whereas in non-isobaric systems gas transport occurs by advection and diffusion. The equation of mass conservation accounting for gas in a porous media can be written as:

$$
\partial \frac{[C]_{T}}{\partial t}+\frac{\partial N}{\partial x}+r_{a}=0
$$

where:

$$
\begin{gathered}
N=-D_{w, e} \frac{\partial[C]_{g}}{\partial x} \\
{[C]_{T}=\left(\rho_{b} K_{b}+\theta_{w}+\varepsilon_{g} H_{c}\right)[C]_{w}}
\end{gathered}
$$

where, $C_{T}$ : total gas concentration in multi-phases $(\mathrm{g} / \mathrm{L})$, $C_{w}$ : gas concentration in porous pore water $(\mathrm{g} / \mathrm{L}), K_{d}$ : linear adsorption constant $\left(\mathrm{m}^{3} / \mathrm{kg}\right), \rho_{b}$ : bulk density $(\mathrm{kg} /$ $\left.\mathrm{m}^{3}\right), \varepsilon_{g}$ : gas fraction in the porous pores, $\theta_{w}$ : volumetric water content in the porous medium, $H_{c}$ : Henry's constant, $D_{w, e}$ : the effective diffusivity coefficient of gas $\left(\mathrm{m}^{2} / \mathrm{s}\right), r_{a}$ : rate of reaction for gain or loss [21].

The following equation of mass conservation gas diffusion-convection in a porous media can be written:

$$
\varphi \frac{\partial C_{i}}{\partial t}=-\frac{\partial\left(U_{k} C_{i}\right)}{\partial x_{k}}+\frac{\partial}{\partial x_{k}}\left(D_{i k} \frac{\partial C_{i}}{\partial x_{j}}\right)+G_{i}
$$

where: $\varphi$ is porosity of the landfill $\left(\mathrm{m}^{3}\right.$ of voids per $\mathrm{m}^{3}$ of refuse), $C_{i}$ is concentration of the $i^{\text {th }}$ component of the gas mixture $\left(\mathrm{kg} / \mathrm{m}^{3}\right), U_{k}$ is advective velocity in the $k^{\text {th }}$ direction (m/day), $D_{i k}$ is diffusion coefficient of gas $i$ in 
the $k^{\text {th }}$ direction ( $\mathrm{m}^{2} /$ day), $x_{k}$ is $k^{\text {th }}$ direction (m), and $G_{i}$ is generation rate of the $i^{\text {th }}$ component of the gas mixture (kg/day) [17].

Since the Reynolds number characterizing the flow of gases generated in sanitary landfills is typically smaller than 1 , the velocity field can be described by the generalized form:

$$
U_{k}=-\frac{k}{\mu_{M}}\left(\frac{\partial P}{\partial x_{k}}-\delta_{k 3} \rho g\right)
$$

where: $k$ is permeability of the landfill (Darcy), $\mu_{M}$ is viscosity of the gas mixture $\left(\mathrm{N} \cdot\right.$ day $\left./ \mathrm{m}^{2}\right), P$ is total pressure inside the landfill $\left(\mathrm{N} / \mathrm{m}^{2}\right), \rho$ is density of the gas mixture $\left(\mathrm{kg} / \mathrm{m}^{3}\right), \delta_{k 3}$ is Kronecker's delta: $\delta_{13}=\delta_{23}=0$; $\delta_{33}=1$ (dimensionless), and $g$ is acceleration due to gravity $\left(\mathrm{m} / \mathrm{day}^{2}\right)[17]$.

The previous literature introduces to the processes of biogas generation, biogas correlation with functional parameters, and biogas transport, which all are amended, controlled, and/or optimized in the approach of this article.

\section{The Approach}

The main contribution of this research is to provide a novel system for efficient management and utilization for biogas and leachate in biocell landfills. The novel approach of Root Analogous Municipal Solid Waste Management System (RA-MSW) is a system that serves dual mission for biogas and leachate management. The RAMSW is mainly consisted of network simulates tree roots in which the role of these permeable roots is to recirculate leachate and collect biogas interchangeably where the circulation of leachate is controlled as shown in Figures 1 and 2.

The biological biogas production and leachate treat- ment are affected by the major parameters of nutrients, water content, $\mathrm{pH}$, and temperature. Hence, the process of leachate recirculation is controlled by fitting the abovementioned parameters to optimal biogas production and leachate treatment (Figure 2) The advantages of RAMSW are summarized to the following major points:

- Dual handling for leachate and biogas;

- Hydrophobic permeable roots for gas collection [2224];

- Efficient and smooth biogas transport;

- Controllable system for waste management;

- Enhanced biogas production;

- Fast waste stabilization;

- The system raw material are available on the dump;

- The application of 5 R's concept for solid waste management.

This new system provides amendment on leachate recirculation, biogas production, leachate treatment, and biogas collection as shown in Figure 3.

\section{The RA-MSW System Design}

The permeable medium of roots is a hydrophobic material such as polymers (e.g. polystyrene (PS), polyethylene $(\mathrm{PE}) \cdots$ ) that could be found in the refuse frequently. For investigation of gas transport within root-like polymer, permeability test is conducted using air flow through different comparable media where hydrophobic styrofoam polymer shows high permeability (Figure 4). The temperature, porosity, and water content are vital factors affecting the biogas transport in porous media. Due to high porosity and low water content in styrofoam; more efficient biogas transport (convection and diffusion) could be predicted. The temperature effect could vary from one gas to another. Figures 5 and $\mathbf{6}$, show the effect of temperature variation on coefficient of diffusion $(D)$ and

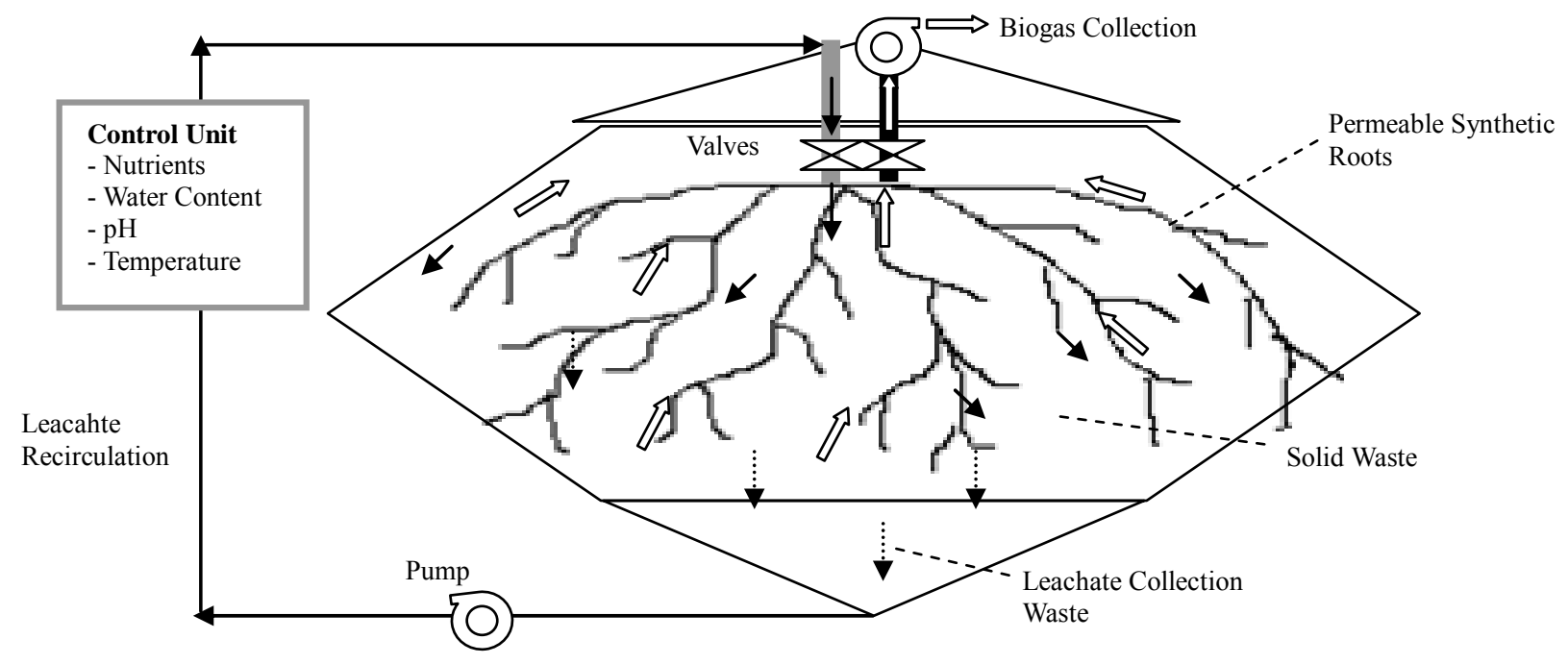

Figure 1. RA-MSW biocell system. 


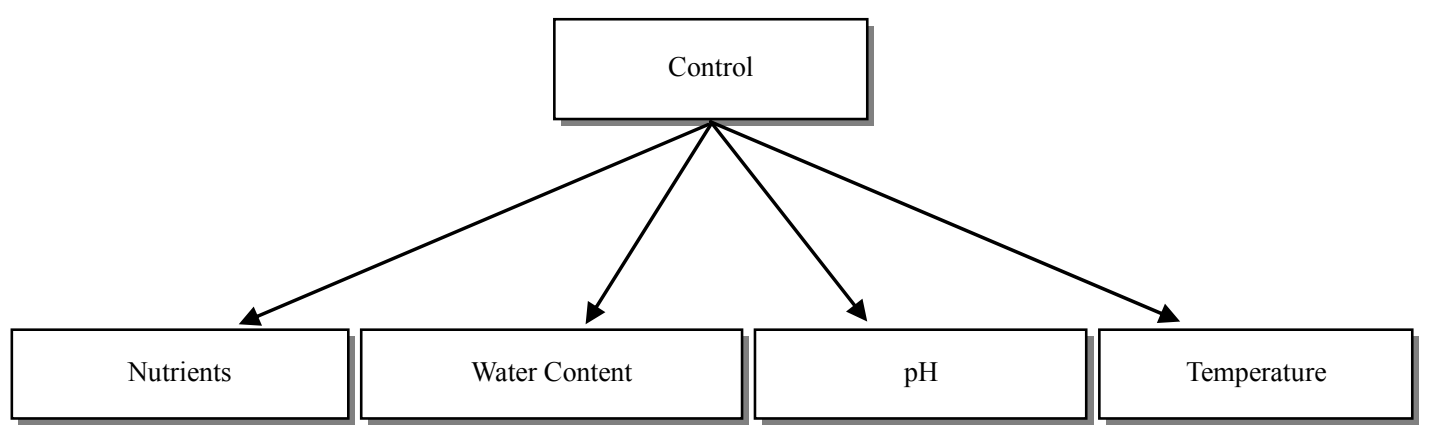

Figure 2. The parameters that are controlled in RA-MSW management system for efficient waste manipulation.

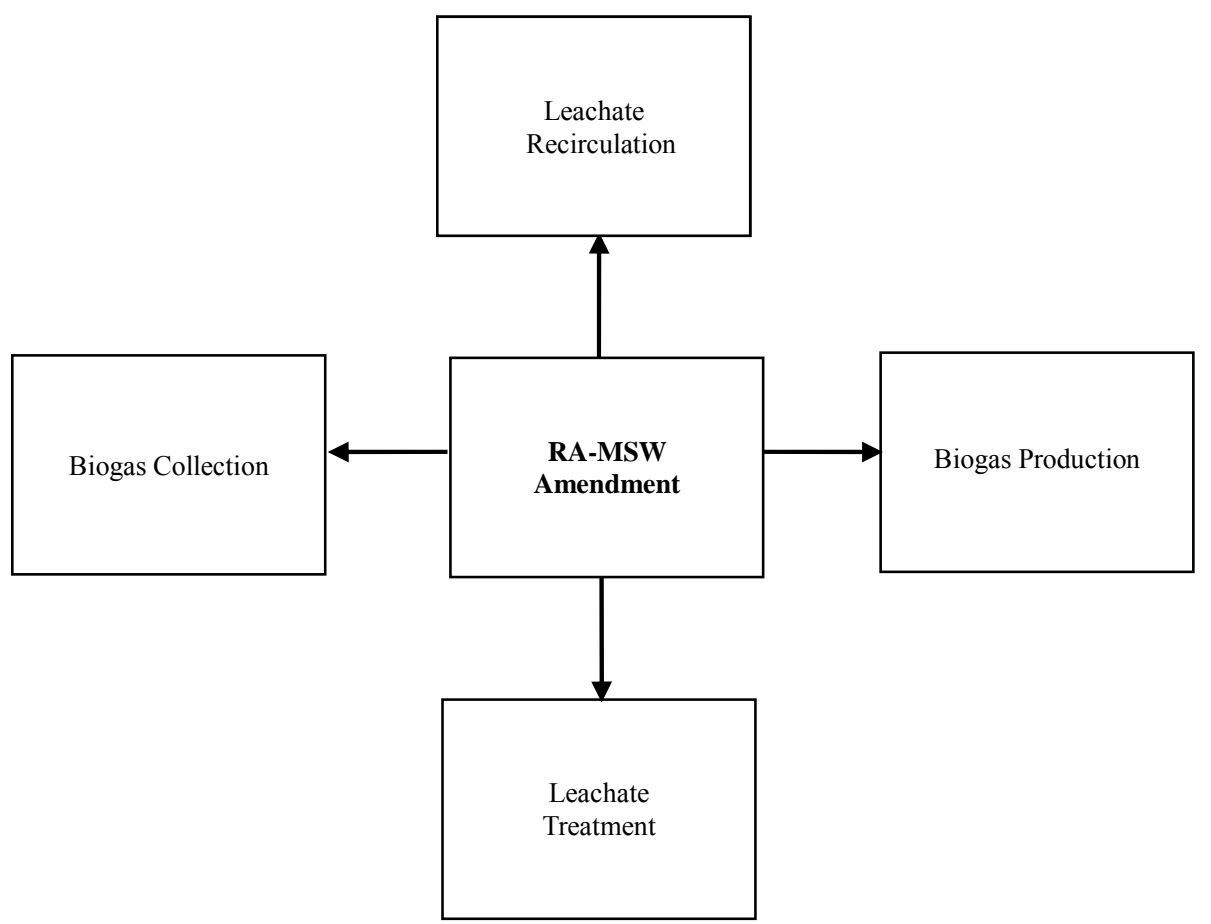

Figure 3. The affected processes benefited by applying RA-MSW system.

coefficient of conductivity $(K)$ for simulation of biogas transport in permeable polymer (polystyrene medium). To fulfill sustainable development principles, polymers used for permeable medium is formed from recyclable materials available on the landfill mass. Another source of sustainable materials for roots is the wasted polymers during flawed polymerization processes taking place occasionally in the factories.

\section{RA-MSW Fabrication and Operations}

RA-MSW roots are hydrophobic and porous polymer medium. These roots can be formed either on site or in factory. At a landfill, there are many sources of plastic and hydrophobic materials available at the dump. Styrofoam material is one of the hydrophobic materials that can be reformed for RA-MSW roots fabrication. There are two scenarios suggested of operation; the first is to pack the solid waste and compact it and then bore holes are drilled. The melted polymer is then poured and reformed with steam bubbling for high porosity; in this case porous roots should not be clogged. The other scenario is to have the tube-like roots formed with the required specification at factory and then roots are installed while cell is being operated. In this case the roots must not be compacted and should still be hollow for leachate and biogas conveyance. However, in any condition, roots have to be properly oriented with full consideration of avoiding compaction and shearing.

\section{Waste Stabilization in RA-MSW}

In landfill cells, waste biodegradation is accomplished by aerobic processes that are followed by anaerobic processes. These two processes are important for waste degradation and biogas generation. The permeable polymer 


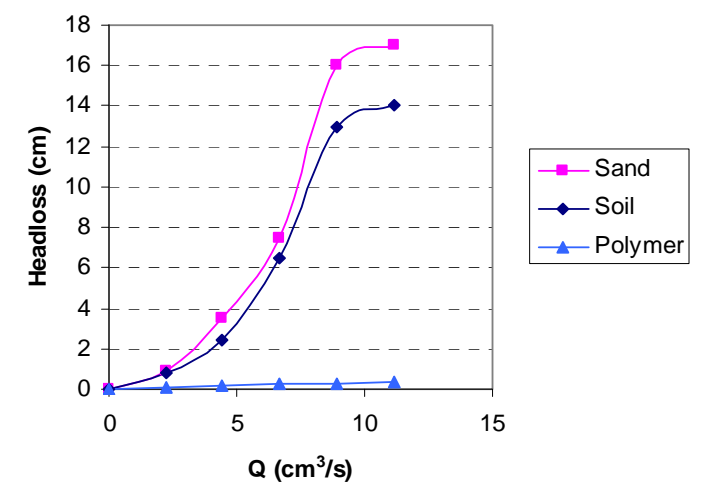

Figure 4. Head loss vs air flow rate within different media (at standard conditions).

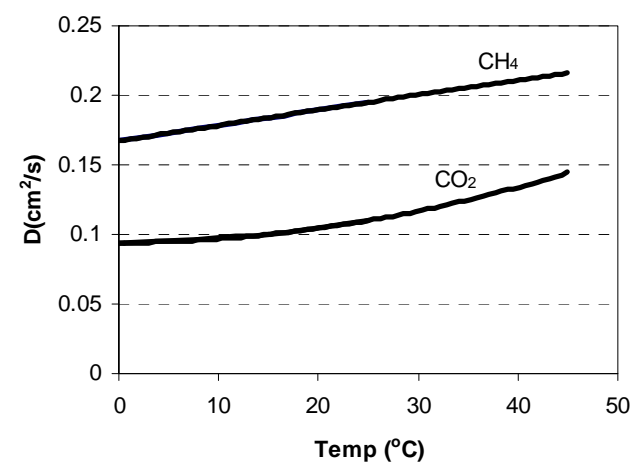

Figure 5. Effect of temperature variation on coefficient of diffusion (D) for simulation of biogas in polystyrene roots.

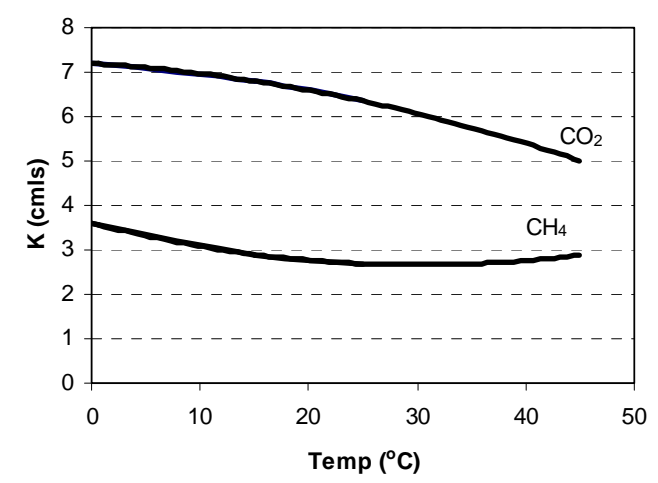

Figure 6. Effect of temperature variation on coefficient of conductivity (K) for simulation of biogas in polystyrene roots.

is used to collect biogas and recirculate leachate generated through biological processes. In addition, these roots could be used to intrude air in a third aerobic process that follows the anaerobic process to stimulate waste biodegradation in the cells. In each finished cell, roots are connected to valves and piping system that convey biogas to a storage volume (Figure 1).

Furthermore, biogas produced within RA-MSW system begins to move in the least resistant pathway toward the areas of less pressure and concentration. Biogas transfer could be forecasted as shown in Figures $\mathbf{5}$ and $\mathbf{6}$, biogas smoothly moves through the homogenous roots where there is no pressure build up, no inactive zone obstruction, and no heterogeneous gas transfer. Biogas tends to transport toward the permeable evacuated RAMSW and then they are collected at ports.

\section{RA-MSW Management System}

RA-MSW controls the fluid wastes (leachate and biogas). It is also a platform to enhance biogas production and it is flexible to apply successive aerobic-anaerobic processes and leachate recirculation which in turn increase waste degradation and stabilization.

US EPA developed the solid waste management pyramid, which ranked the most preferable ways to address solid waste management. Source reduction and reuse, was listed as the best approach; followed by recycling, recovery, and disposal (Figure 7). This approach is being modified in RA-MSW management system, which provides enhanced biogas production, better control of greenhouse biogas emissions, and landfill leachate treatment.

RA-MSW system is also a modern method for reusing and recycling materials at the dump. It is then a state of the art technology for solid waste management with new 5 R's approach. The 5 R's cycle approach suggests the following:

- Reduce the waste from source;

- Reuse the waste for the same function;

- Recycle the waste for other functions;

- Recover energy and material from waste;

- Reprocess the residual output waste in new product.

The 5 R's cycle approach suggests no place for waste refuse as shown in Figure 8. Prospective advantages of RA-MSW management system include:

- Integrated operation system that combines waste disposal, biogas production enhancement, biogas collection, and leachate recirculation;

- Fast decomposition and biological stabilization of the waste;

- More control on released waste (biogas and leachate);

- Smooth and fast transfer of biogas from waste to the roots;

- Control on waste toxicity and mobility via control on both aerobic and anaerobic conditions;

- It is a new generation of bioreactor landfill (biocells);

- Application of "5 R's" cycle approach in solid waste management.

\section{Conclusion}

This paper provides a novel MSW management system for waste utilization for bioreactor landfill (biocell). The (RA-MSW) provides new approach of hydrophobic polymer roots for dual mission of biogas and leachate 


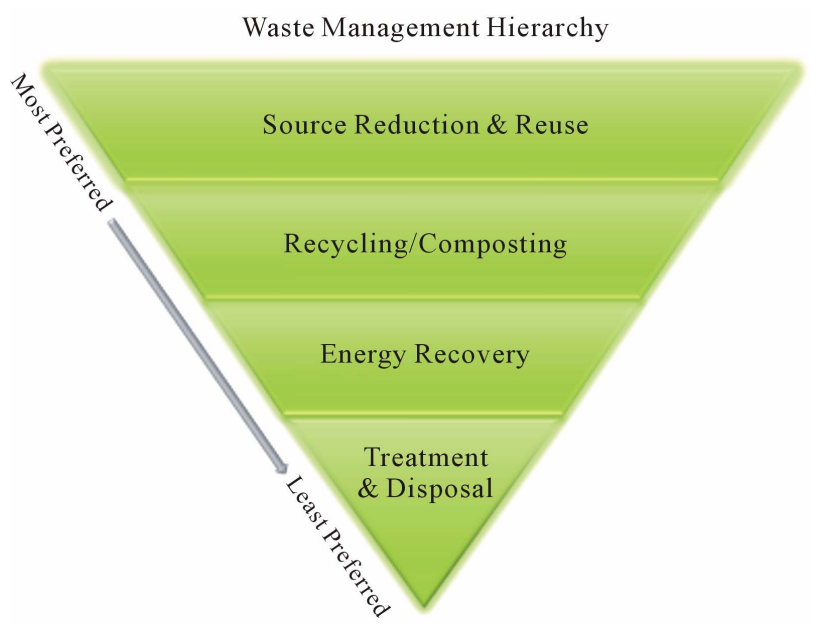

Figure 7. U.S. EPA solid waste management pyramid [25].

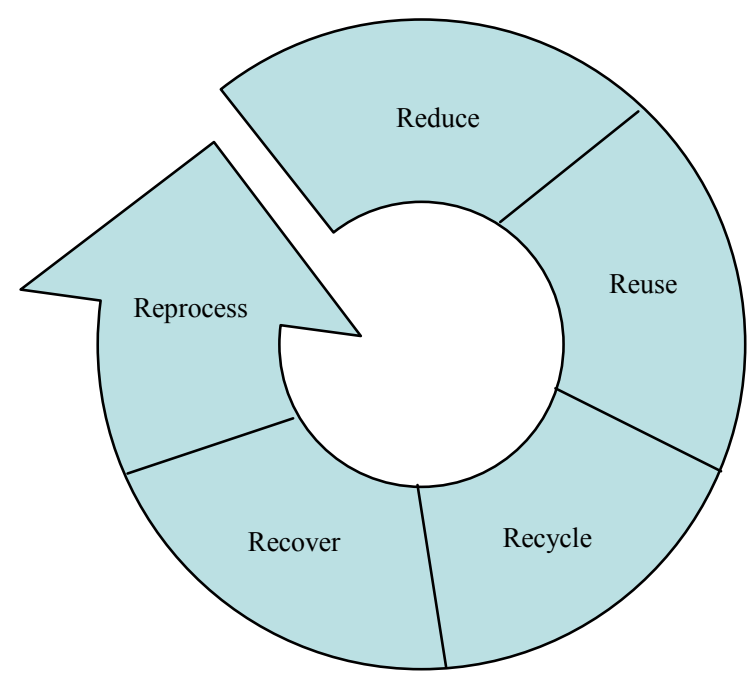

Figure 8. The new 5 R's cycle approach for solid waste management.

manipulation. It gives amendments for landfill configuration, waste operation, biogas collection, and leachate treatment. RA-MSW system is a modern method for reusing and recycling materials at the dump. It is a state of the art technology with new 5 R's cycle approach for solid waste management and energy utilization.

\section{Acknowledgements}

The Deanship of Research and Deanship of Engineering in Jerash University is gratefully acknowledged.

\section{REFERENCES}

[1] P. M. Czepiel, J. H. Shorter, B. Mosher, E. Allwine, J. B. McManus, R. C. Harriss, C. E. Kolb and B. K. Lamb, "The Influence of Atmospheric Pressure on Landfill Methane Emissions," Waste Management, Vol. 23, No. 7, 2003, pp. 593-598. doi:10.1016/S0956-053X(03)00103-X
[2] K. Wang-Yao, S. Towprayoon, C. Chiemchaisri, S. H. Gheewala and A. Nopharatana, "Seasonal Variation of Landfill Methane Emission from Seven Solid Waste Disposal Sites in Central Thailand," The 2nd Joint International Conference on Sustainable Energy and Environment (SEE 2006), Bangkok, 21-23 November 2006, pp. 1-4.

[3] T. Ishigaki, M. Yamada, M. Nagamori, Y. Ono and Y. Inoue, "Estimation of Methane Emission from Whole Waste Landfill Site Using Correlation between Flux and Ground Temperature," Environmental Geology, Vol. 48, No. 7, 2005, pp. 845-853.

[4] J. C. Stern, J. Chanton, T. Abichou, D. Powelson, L. Yuan, S. Escoriza and J. Bogner, "Use of Biologically Active Cover to Reduce Landfill Methane Emissions and Enhance Methane Oxidation," Waste Management, Vol. 27, No. 9, 2007, pp. 1248-1258. doi:10.1016/j.wasman.2006.07.018

[5] R. N. Kinman, D. L. Nutini, J. J. Walsh, W. G. Vogt, J. Stamm and J. Rickabaugh, "Gas Enhancement Techniques in Landfill Simulators," Waste Management and Research, Vol. 5, No. 1, 1987, pp. 13-25.

[6] D. R. Reinhart and A. B. Al-Yousfi, "The Impact of Leachate Recirculation on Municipal Solid Waste Landfill Operating Characteristics," Waste Management and Research, Vol. 14, No. 4, 1996, pp. 337-346.

[7] D. R. Reinhart and T. G. Townsend, "Landfill Bioreactor Design and Operation," Lewis Publishers, Boca Raton, 1998.

[8] H. Zhang, P. He and L. Shao, "Methane Emissions from MSW Landfill with Sandy Soil Covers under Leachate Recirculation and Subsurface Irrigation," Atmospheric Environment, Vol. 42, No. 22, 2008, pp. 5579-5588.

[9] T. H. Christensen, P. Kjeldsen and B. Lindhardt, "GasGenerating Processes in Landfills," In: T. H. Christensen, R. Cossu and R. Stegmann, Eds., Landfilling of Waste: Biogas, E \& FN Spon, London, 1996, pp. 25-50.

[10] A. Isci and G. N. Demirer, "Biogas Production Potential from Cotton Wastes," Renewable Energy, Vol. 32, No. 5, 2007, pp. 750-757. doi:10.1016/j.renene.2006.03.018

[11] P. T. Williams, "Waste Treatment and Disposal," 2nd Edition, John Wiley \& Sons Ltd., Chichester, 2005, pp. 171-244.

[12] N. M. Naranjo, J. A. Meima, A. Haarstrick and D. C. Hempel, "Modelling and Experimental Investigation of Environmental Influences on the Acetate and Methane Formation in Solid Waste," Waste Management, Vol. 24, No. 8, 2004, pp. 763-773. doi:10.1016/j.wasman.2004.04.006

[13] K. R. Gurijala, P. Sa and J. A. Robinson, "Statistical Modeling of Methane Production from Landfill Samples," Applied and Environmental Microbiology, Vol. 63, No. 10, 1997, pp. 3797-3803.

[14] K. Sormunen, M. Ettala and J. Rintala, "Detailed Internal Characterization of Two Finnish Landfills by Waste Sampling," Waste Management, Vol. 28, No. 1, 2008, pp. 151-163. doi:10.1016/j.wasman.2007.01.003

[15] D. Tecle, J. Lee and S. Hasan, "Quantitative Analysis of 
Physical and Geotechnical Factors Affecting Methane Emission in Municipal Solid Waste Landfill," Environmental Geology, Vol. 56, No. 6, 2008, pp. 1135-1143.

[16] P. McCarty, X. Tong, L. Smith and J. Bae, "Mechanisms of Bacterial Hydrolysis of Lignocellulosic Materials," Draft Annual Report, Contract No. PL-86-1, Department of Civil Engineering, Stanford University, 1986.

[17] M. El-Fadel, A. Findikakis and J. Leckie, "Numerical Modeling of Generation and Transport of Gas and Heat in Landfills I. Model Formulation," Waste Management \& Research, Vol. 14, No. 5, 1996, pp. 483-504.

[18] V. Popov and H. Power, "DRM-MD Approach for the Numerical Solution of Gas Flow in Porous Media, with Application to Landfill," Engineering Analysis with Boundary Elements, Vol. 23, No. 2, 1999, pp. 175-188. doi:10.1016/S0955-7997(98)00054-X

[19] P. McCarty, "Thermodynamics of Biological Synthesis and Growth," Proceedings of 2nd International Water Pollution Research Conference, Pergamon Press, New York, 1965, pp. 169-187.

[20] M. Nastev, R. Therrien, R. Lefebvre and P. Gélinas, "Gas
Production and Migration in Landfills and Geological Materials," Journal of Contaminant Hydrology, Vol. 52, No. 1-4, 2001, pp. 187-211. doi:10.1016/S0169-7722(01)00158-9

[21] K. Valsaraj, "Elements of Environmental Engineering: Thermodynamics and Kinetics," Lewis Publishers, CRC Press, Inc., Boca Raton, 1995.

[22] Q. Ahmad, E. Maria and J. Iwona, "Investigation and Fuzzy Regime for Biogas Transport in Hydrophobic Permeable Polymer," Annual Meeting of the North American on Fuzzy Information Processing Society, Montreal, 3-6 June 2006, pp. 25-30.

[23] Q. Ahmad, E. Maria and J. Iwona, "Intelligent Fuzzy Control for Biogas in Hydrophobic Polymer System," IEEE International Symposium on Industrial Electronics, Montreal, 9-13 July 2006, pp. 252-256.

[24] Q. Ahmad, E. Maria and J. Iwona, "Intelligent Novel Solid Waste Management System (QEJ Bricks Biocell Approach)," Hypothesis, Vol. 8, No. 1, 2010, pp. 1-14.

[25] US EPA, "Solid Waste Management Pyramid," 2012. http://www.epa.gov/osw/nonhaz/municipal/hierarchy.html 